\title{
PREVALENCE OF THE
}

\section{HEMOCHROMATOSIS GENE} MUTATION IN PATIENTS WITH NONALCOHOLIC STEATOHEPATITIS AND CORRELATION WITH DEGREE OF LIVER FIBROSIS

\author{
Idilio ZAMIN Jr., Angelo Alves de MATTOS, Ângelo Zambam de MATTOS, \\ Eduardo MIGON, Claudia BICA and Cláudio Osmar Pereira ALEXANDRE
}

\begin{abstract}
Background - Nonalcoholic steatohepatitis is a chronic liver disease with a high prevalence in the general population and a potential to evolve into cirrhosis. It is speculated that iron overload could be associated with liver injury and unfavorable progress in affected patients. Aims - To evaluate the prevalence of mutation of the hemochromatosis gene (HFE) in patients with nonalcoholic steatohepatitis and to correlate it with histological findings in liver specimens. Patients and Methods - Twenty-nine patients with nonalcoholic steatohepatitis were evaluated. The presence of mutation in the hemochromatosis gene (C282Y and H63D) was tested in all patients and its result was evaluated in relation to hepatic inflammatory activity, presence of fibrosis, and iron overload in the liver. The control group was composed of 20 patients with normal liver function tests and 20 patients infected with the hepatitis $\mathrm{C}$ virus, with elevated serum levels of aminotransferases and with chronic hepatitis as shown by biopsy. Results - Mutation of the hemochromatosis gene (C282Y and/or H63D) was diagnosed in 16 $(55.2 \%)$ patients with nonalcoholic steatohepatitis, in $12(60 \%)$ patients with hepatitis $\mathrm{C}$ and in $8(40 \%)$ patients with no liver disease. No association was found between the presence of mutation and inflammatory activity, nor with the presence of fibrosis in patients with nonalcoholic steatohepatitis. An association was found between the presence of mutation and the occurrence of iron overload in liver, but there was no association between liver iron and the occurrence of fibrosis. Conclusions - The findings suggest that iron does not play a major role in the pathogenesis and progression of nonalcoholic steatohepatitis, and routine tests of the hemochromatosis gene mutation in these patients should not be recommended.

HEADINGS - Hemochromatosis. Fatty liver. Liver cirrhosis.
\end{abstract}

\section{INTRODUCTION}

Nonalcoholic steatohepatitis (NASH) is a chronic liver disease characterized by diffuse fatty infiltration and inflammation. Previously considered to be benign, NASH has the potential to progress to fibrosis, cirrhosis and hepatocellular carcinoma in some patients ${ }^{(3,10,19,26,29,32,34)}$. It was first described in 1980 by LUDWIG et al. ${ }^{(26)}$, based on the study a group of patients who lacked a history of substantial alcohol consumption, but had findings on liver biopsy that could not be distinguished from those of patients with alcoholic hepatitis. The authors also called attention to the association of the disease with obesity, female sex and diabetes mellitus, as well as to its potential of progressing.

The prevalence of NASH remains unknown, especially because of its silent, asymptomatic course in most patients. However, it is estimated to be high, particularly in countries where obesity is common ${ }^{(2,36)}$. In our community, after evaluating 912 obese individuals without associated diabetes mellitus in a nutrition ward, the prevalence of NASH was $3.18 \% \%^{(37)}$. This prevalence, however, is underestimated, since only patients with elevated aminotransferases were evaluated.

Supported by the Brazilian Research Council (CNPQ).

Department of Gastroenterology, Santa Casa University Hospital, "Fundação Faculdade Federal de Ciências Médicas de Porto Alegre”, RS, Brazil. Address for correspondence: Dr. Idilio Zamin Jr. - Rua Armando Pereira Câmara, 111/801 - 90470-100 - Porto Alegre, RS, Brazil. E-mail: izamin@terra.com.br 
With regard to its potential progression, it is interesting to recall the work by CALDWELL et al. ${ }^{(13)}$, who reviewed 102 cases of patients with a diagnosis of cryptogenic cirrhosis. The authors observed that there was a clear predominance of obese women, patients with diabetes mellitus and the elderly, similar to what is observed in patients with NASH, and they concluded that many cases of cirrhosis considered as "cryptogenic" could actually be secondary to NASH.

Many doubts surround NASH in the literature yet, especially with regard to its etiopathogenesis ${ }^{(3,19,26,29,32,34)}$. At the same time, due to its potential to evolve into cirrhosis, it is important to identify the factors associated with the progression to fibrosis. In this regard, old age, female sex, presence of diabetes mellitus, obesity, high levels of free fatty acids, and high degree of inflammatory activity on liver biopsy are considered factors of greater risk for the presence and progression of fibrosis ${ }^{(1,22,30,34)}$. The presence of alanine aminotransferase (ALT)/aspartate aminotransferase (AST) proportion above 1 was also associated with a higher degree of fibrosis in patients with $\mathrm{NASH}^{(33,34)}$. Finally, there are conflicting results on the presence of iron overload and its influence in inducing fibrosis, as well as on the role played by the mutation of the hemochromatosis gene (HFE) in this context ${ }^{(8,15,17,23,35)}$.

The two most frequently recognized inherited mutations of HFE result in amino acid substitutions at positions 282 (cysteine to tyrosine, C282Y) and 63 (histidine to aspartic acid, H63D) ${ }^{(20)}$. Over $90 \%$ of patients with hereditary hemochromatosis are homozygous for at least one of these mutations ${ }^{(20)}$. The significance of heterozygosity for these mutations is unclear, but there have been reports of an association with liver iron overload and with increased liver fibrosis in patients with $\mathrm{NASH}^{(17,23)}$.

The aim of the present study was to evaluate the presence of mutations of the hemochromatosis gene in patients with nonalcoholic steatohepatitis and to correlate it with the severity of histological findings.

\section{PATIENTS AND METHODS}

Twenty-nine obese patients with a diagnosis of NASH cared for at the Gastroenterology Unit of the "Irmandade Santa Casa de Misericórdia de Porto Alegre", Porto Alegre, RS, Brazil, were prospectively evaluated.

Patients with alcohol intake $>20 \mathrm{~g} /$ day, use of potential hepatotoxic drugs, or occupational exposure to agents capable of causing liver damage were excluded during the evaluation. Viral (anti-HBc, HBsAg, anti-HCV and anti-HIV) and autoimmune (antinuclear antibody, smooth muscle antibody and antimitochondrial antibody) tests were requested for all patients, so as to exclude from the study patients who were positive for these markers, as well as those with diabetes mellitus, the patients who were under 18 or over 65 years of age, or who were pregnant.

The following laboratory tests were requested to the patients included in the protocol: blood count, platelet count, bilirubins, ALT, AST, alkaline phosphatase, gama glutamyltransferase, prothrombin time, protein count, serum iron, ferritin, and transferrin saturation.

In order to diagnose NASH, obese patients (body mass index above $30 \mathrm{~kg} / \mathrm{m}^{2}$ ) with aminotransferase alterations were submitted to liver biopsy after informed consent. Specimens were stained with hematoxylin-eosin and Sirius red (collagen identification). Hepatic iron was assessed by the grade of Perls' Prussian blue staining. Biopsies were examined by a single pathologist who was unaware of the patients' data.

The presence of macrovesicular steatosis associated with lobular inflammatory infiltrate, with or without perisinusoidal fibrosis, and with hepatocellular injury was considered as the histological criterion for diagnosing NASH. Hepatocellular injury was defined as ballooning degeneration of hepatocytes ${ }^{(27)}$. Grading and histologic staging were according to BRUNT et al. ${ }^{(9)}$.

A total of 29 patients were evaluated, $19(65.52 \%)$ females and $10(34.48 \%)$ males. Twenty-five patients $(86.2 \%)$ were Caucasian, two $(6.8 \%)$ were black, and two $(6.8 \%)$ were halfcaste. The mean age ( \pm standard deviation) was $42.2 \pm 11.9$ years, and the mean body mass index was $38.4 \pm 7.4 \mathrm{~kg} / \mathrm{m}^{2}$.

Twenty patients with no history of liver disease were used as controls. They had visited the Gastroenterology Unit with dyspeptic symptoms and presented normal liver function tests. Twelve $(60 \%)$ were females and eight $(40 \%)$ were males. Fourteen patients $(70 \%)$ were Caucasian and six $(30 \%)$ were half-caste, with mean age of 46.4 \pm 15.3 years. A second control group was also evaluated, composed of hepatitis $\mathrm{C}$ virus carriers with elevation in serum levels of AST and ALT and biopsy showing chronic hepatitis. Twelve patients $(60 \%)$ were Caucasian, five (25\%) were half-caste, and three (15\%) were black, with mean age of $43.8 \pm 12.5$ years.

The presence of HFE mutations was verified by means of restriction fragment length polymorphism on the polymerase chain reaction (PCR) products of genomic DNA extracted from peripheral blood mononuclear cells ${ }^{(20)}$. Extracted DNA fragments were amplified using oligonucleotide primers for the Cys282Tyr and His63Asp loci synthesized according to previously reported sequences ${ }^{(20)}$. Amplification, digestion, and visualization of the PCR products were performed as previously reported ${ }^{(20,25)}$. The resulting PCR products were confirmed by sequenced using an ABI 310 sequencer (Perkin-Elmer, Foster City, CA, USA). Sequence comparisons of the marker were performed using BLAST analysis of the GenBank database.

The project for the present study was approved by the Ethical Committee of the "Irmandade Santa Casa de Misericórdia de Porto Alegre".

For the statistical analysis, data were plotted in an Excel data sheet and analyzed using the statistical package SPSS 9.0 through descriptive and analytical statistics. Comparisons were done using Person's Chi-square test, and the significance level was 5\%.

\section{RESULTS}

HFE Mutation - among patients with NASH, 13 (44.8\%) were normal; mutation $\mathrm{C} 282 \mathrm{Y}$ (heterozygous) was observed in 10 patients (34.4\%); mutation H63D (heterozygous) was observed in four patients $(13.7 \%)$; one patient $(3.4 \%)$ was homozygous for mutation H63D, and one patient (3.4\%) presented both mutations in heterozygosis (compound heterozygous). Among the patients with chronic hepatitis C, eight ( $40 \%$ ) were normal; mutation C 282 Y (heterozygous) was observed in seven patients $(35 \%)$, mutation H63D (heterozygous) was observed in one (5\%), and four patients 
$(20 \%)$ presented both mutations in heterozygosis (compound heterozygous). Among the patients without liver disease, 12 (60\%) were normal, mutation $\mathrm{C} 282 \mathrm{Y}$ (heterozygous) was detected in 5 patients (25\%), mutation H63D (heterozygous) was observed in 1 $(5 \%)$, and 2 patients $(10 \%)$ presented both mutations in heterozygosis (compound heterozygous). Table 1 shows these data.

TABLE 1 - Prevalence of HFE mutations in patients with NASH and in control groups $(\mathrm{P}=0.41)$

\begin{tabular}{lcc}
\hline Patients & $\begin{array}{c}\text { Absence } \\
\text { of mutation }\end{array}$ & $\begin{array}{c}\text { Mutation of gene } \\
\text { (C282Y and/or H63D) }\end{array}$ \\
\hline NASH & $13(44.8 \%)$ & $16(55.2 \%)$ \\
Chronic hepatitis C & $8(40 \%)$ & $12(60 \%)$ \\
Patients without liver disease & $12(60 \%)$ & $8(40 \%)$ \\
\hline
\end{tabular}

By grouping the patients according to the presence or absence of mutation, it was shown that the prevalence of mutation of the hemochromatosis gene was similar among the groups $(P=0.41)$.

The results obtained through sequencing confirmed those by PCR-RFLP.

Laboratory tests of iron metabolism in patients with NASH - Iron serum levels were within the normal range $(72.2$ $\pm 33.5 \mu \mathrm{g} / \mathrm{dL}$ ) in all patients, as well as transferrin saturation $(26.4 \pm 5.9 \%)$. Ferritin, however, was above the normal range in 20 patients $(258 \pm 109 \mathrm{ng} / \mathrm{mL})$. Among the patients with elevated ferritin serum levels, $12(60 \%)$ presented mutation of the HFE, and $8(40 \%)$ did not $(P>0.05)$.

Liver histology in patients with NASH - Fibrosis was present in 21 patients $(72.4 \%$ ) with NASH, 13 of whom presenting mutation of the HFE. There was no statistically significant association between the presence of mutation and that of fibrosis $(P>0.05)$.

Inflammatory activity was considered mild in 21 patients $(72.4 \%)$ and moderate or severe in $8(27.6 \%)$. No association between inflammatory activity and mutation of the HFE was observed $(P>0.05)$.

In only five patients it was detected iron overload in the liver, all of whom presenting mutation of the HFE as well as fibrosis. However, fibrosis was present in 16 other patients who did not present iron overload. Therefore, no significant association between the presence of iron overload and the occurrence of fibrosis in the liver was found $(P>0.05)$. There was no association between ferritin levels and the presence of iron deposits.

Table 2 summarizes the histological findings concerning mutation of the HFE.

TABLE 2 - Liver histology in patients with NASH as regards HFE mutations

\begin{tabular}{lccc}
\hline Characteristics & Normal & $\begin{array}{c}\text { Mutation of gene } \\
\text { C282Y/H63D }\end{array}$ & $\boldsymbol{P}$ \\
\hline Fibrosis & 5 & 3 & \\
$\quad$ absent & & 13 & $>0.05$ \\
$\quad$ present & 8 & & $>0.05$ \\
Inflammatory activity & 10 & 11 & $>0.05$ \\
$\quad$ mild & 3 & 5 & $>0.05$ \\
$\quad$ moderate-severe & 0 & 5 & $<0.05$ \\
Iron overload & & & \\
\hline
\end{tabular}

\section{DISCUSSION}

The prevalence of the mutation of the HFE in the general population varies according to the different studies and mainly depending on the race of the population investigated. Some studies observed mutation $\mathrm{C} 282 \mathrm{Y}$ in $10 \%-20 \%{ }^{(4,12)}$, while mutation H63D is described in $15 \%-40 \%$ of the population ${ }^{(4,31)}$. Both mutations are more common in Caucasian patients. BARRY et al. ${ }^{(6)}$, in a population based study, evaluated the prevalence of HFE mutations in newborns and noted that $30 \%$ of them carried a mutation in the gene and that $6 \%$ had two mutations. OLYNYK et al. ${ }^{(28)}$, in another population based study, observed heterozygozity of C282Y mutation in $14.1 \%$ of cases. H63D was associated with $\mathrm{C} 282 \mathrm{Y}$ mutation (compound heterozygous) in $2.2 \%$. In this study, the authors have not published the prevalence of isolated H63D mutation. In Italy, CASSANELLI et al. ${ }^{(14)}$ researched HFE mutations in blood donors and noticed prevalences of $3 \%$ and $24.1 \%$ for $\mathrm{C} 282 \mathrm{Y}$ and $\mathrm{H} 63 \mathrm{D}$ mutations, respectively.

When a mutation occurs, even in heterozygosis, patients often present iron overload in the liver, and this iron may be an inductor of fibrosis in $\mathrm{NASH}^{(23)}$

Alterations in laboratory tests concerning iron metabolism are common to several chronic liver disorders ${ }^{(19,33)}$ and happen mainly in patients with disease of hepatocellular pattern. These alterations are observed in up to $50 \%$ of patients with alcoholic liver disease ${ }^{(21)}$ or with $\mathrm{NASH}^{(3,8,15,35)}$, and usually it is ferritin that is elevated, although serum iron or transferrin may occasionally be altered too. These patients often present iron overload in liver. However, the physiopathogeny and the consequences this overload may have are unclear.

The studies designed to evaluate the presence of HFE mutation in patients with alcoholic liver disease did not find increased prevalence as compared to the control population ${ }^{(24)}$. They did not find any association of the presence of mutation with serum tests of iron metabolism, neither with the presence of iron accumulation and the occurrence of greater liver injury ${ }^{(5,24)}$.

In NASH, however, the role of iron is still uncertain with regard to its physiopathogeny or as an inducer of fibrosis. Early published articles concerning NASH did not comment on the presence of iron overload in liver ${ }^{(19,26,32,34)}$. In 1994, BACON et al. ${ }^{(3)}$, evaluating 33 patients with NASH, reported abnormal results of iron and ferritin serum levels in $58 \%$ of cases. None of the patients presented evidence of primary hemochromatosis, despite showing iron overload in liver. This study was not designed to investigate the connection between iron and NASH, but the authors called attention for a potential association.

GEORGE et al. ${ }^{(23)}$ evaluated 51 patients with NASH and demonstrated that $31 \%$ presented mutation $\mathrm{C} 282 \mathrm{Y}$, being considered heterozygous. The authors noted that these patients presented greater serum levels of transferrin, higher iron concentration in the liver, and more severe liver injury, mainly with greater fibrous expansion. They believe a mild iron overload, as it occurs in a heterozygous patient for hemochromatosis, may act synergistically in promoting fibrosis in NASH.

However, two other studies ${ }^{(7,3)}$ designed to assess the role of iron in NASH did not find any association of it with the occurrence 
of fibrosis or with necrotic inflammatory activity, suggesting that iron does not play a major role in NASH. It must be highlighted that these last two studies did not evaluate HFE mutation.

BONKOVSKY et al. ${ }^{(8)}$ evaluated 36 Caucasian patients with NASH with regard to HFE and compared them to normal subjects They observed mutation C282Y in $19.4 \%$ and mutation H63D in $50 \%$ of patients with NASH. In the control group, mutations $\mathrm{C} 282 \mathrm{Y}$ and $\mathrm{H} 63 \mathrm{D}$ were detected in $11.2 \%$ and $29.3 \%$, respectively. The overall prevalence of HFE mutation observed in patients with NASH $(69.4 \%)$ was significantly greater than in the control population (40.5\%), and from the histological analysis the authors noted that patients with NASH who presented mutation $\mathrm{C} 282 \mathrm{Y}$ had significantly more fibrosis.

CHITTURI et al. ${ }^{(15)}$ investigated mutation of the HFE in 59 patients with NASH and compared it with a control group of blood donors. The authors noted the presence of mutation $\mathrm{C} 282 \mathrm{Y}$ in $22 \%$ of the patients with NASH, significantly above the $9.9 \%$ of the controls. However, mutation H63D was less frequent in patients with NASH $(19 \%)$ than in the control group $(33 \%)$. Therefore, in the overall analysis, the prevalence of mutation of the HFE was similar in the patients with NASH and in the blood donors. In this study the presence of mutation was not associated with greater fibrous expansion in liver.

BUGIANESI et al. ${ }^{(11)}$ evaluated, prospectively, a cohort of 263 patients with nonalcoholic fatty liver disease to define the relative impact of iron overload and HFE mutations on the severity of liver fibrosis. Through a univariate analysis the authors noted that older age, female sex, overweight, AST/ALT ratio greater than 1 , resistance to insulin, histologic features (high degree of necroinflammation and steatosis) and elevated ferritin levels were independent predictors of severe fibrosis. However, levels of ferritin reflected inflammatory activity and were not associated with iron overload in the liver. In this study, the prevalence of HFE mutations (C282Y and H63D) was similar to that of the general population, and iron overload and HFE mutations did not contribute significantly to hepatic fibrosis in patients with NASH.

The prevalence of HFE mutation is highly variable depending on the race investigated, occurring mainly in Caucasian patients.
Since Brazil is a highly racially mixed nation, we thought it was relevant to evaluate its role in patients with NASH, as ours is a population which differs from those of most studies designed to correlate HFE mutation and NASH.

In the present study, the prevalence of HFE mutation $(\mathrm{C} 282 \mathrm{Y}$ and/or H63D) in patients with NASH was 55.2\%, which was not statistically different from that of patients with chronic hepatitis $\mathrm{C}$ $(60 \%)$ and patients without liver disease $(40 \%)$. These results are in accordance with those that think that HFE mutation does not play a major role in the pathogeny of $\mathrm{NASH}^{(7,11,15,35)}$, since it seems to occur at the same frequency in patients with and without chronic liver disease. When we analyzed the mutation of the HFE with regard to histological findings, we did not observe any association of it with the presence of fibrosis as well as with the degree of necrotic inflammatory activity. These data are in agreement with those reported by CHITTURI et al. ${ }^{(15)}$ and BUGIANESI et al. ${ }^{(11)}$.

In Brazil, DEGUTI et al. ${ }^{\left({ }^{16)}\right.}$ studied the prevalence of HFE mutations in 31 patients with NASH, observing 1.6\% and 14.1\% for $\mathrm{C} 282 \mathrm{Y}$ and H63D mutations respectively. In this study, there was no control group. Despite this, the authors have not found association between the presence of mutation and iron overload in the liver, as well as between the mutations and histological findings. The prevalences of C282Y and H63D mutations were lower than in our study, which could possibly be related to the highly racially mixed population living in Brazil and to regional variations.

Similarly to many studies ${ }^{(3,8,11,15,35)}$, ferritin was altered in most of the patients $(69 \%)$, while serum iron and transferrin saturation were normal. However, no association was observed between ferritin levels and HFE mutation, nor with the presence of iron overload in the liver. Nevertheless, this fact is not surprised at all, since ferritin is a inflammatory marker and appears altered in several situations ${ }^{(5)}$.

In conclusion, the findings of the present study suggest that iron does not play a primary role in the physiopathogeny of NASH, since the prevalence of HFE mutation in patients with NASH seems to be the same as that of control groups and is not associated with fibrosis and necrotic inflammatory activity in the liver. Therefore, routine tests of HFE mutation in these patients should not be recommended. 
Zamin Jr I, Mattos AA, Mattos AZ, Migon E, Bica C, Alexandre COP. Prevalência de mutação para o gene da hemocromatose em pacientes com esteatohepatite não-alcoólica e correlação com o grau de fibrose hepática. Arq Gastroenterol. 2006;43(3): 224-8.

RESUMO-Racional -A esteatohepatite não-alcoólica é uma doença crônica, com elevada prevalência na população e com potencial evolutivo. Especulase que a sobrecarga de ferro possa estar associada com a injúria hepática e com uma evolução desfavorável destes pacientes. Objetivos - Avaliar a prevalência da mutação do gene da hemocromatose (HFE) em pacientes com esteatohepatite não-alcoólica e correlacioná-la com os achados histológicos hepáticos. Pacientes e Métodos - Foram avaliados 29 pacientes com esteatohepatite não-alcoólica. A presença da mutação do HFE (C282Y e H63D) foi testada em todos os pacientes e seu resultado foi avaliado em relação a atividade inflamatória hepática, presença de fibrose e depósitos hepático de ferro. Como grupo controle estudou-se 20 pacientes com provas de função hepática normal e 20 pacientes portadores do vírus da hepatite $\mathrm{C}$, com elevação dos níveis de aminotransferases e biópsia revelando hepatite crônica. Resultados - A mutação do HFE (C282Y e/ou H63D) foi diagnosticada em 16 (55,2\%) pacientes com esteatohepatite não-alcoólica, em 12 (60\%) pacientes com hepatite C e em 8 (40\%) pacientes sem doença hepática. Não se observou associação entre a presença da mutação e a atividade inflamatória e a presença de fibrose nos pacientes com esteatohepatite nãoalcoólica. Foi observada associação entre a presença de mutação e a ocorrência de depósitos de ferro hepático, porém, não ocorreu associação entre o ferro hepático e a ocorrência de fibrose. Conclusões - Os achados sugerem que o ferro não exerce papel importante na patogenia e na evolução da esteatohepatite não-alcoólica e a pesquisa rotineira da mutação do HFE nestes pacientes não deve ser recomendada.

DESCRITORES - Hemocromatose. Fígado gorduroso. Cirrose hepática.

\section{REFERENCES}

1. Angulo P. Nonalcoholic fatty liver disease. N Engl J Med. 2002;346:1221-31.

2. Angulo P, Keach JC, Batts KP, Lindor KD. Independent predictors of liver fibrosis in patients with nonalcoholic steatohepatitis. Hepatology. 1999;30:1356-62.

3. Bacon BR. Hemochromatosis: diagnosis and management. Gastroenterology. 2001;120:718-25

4. Bacon BR, Farahvash MJ, Janney CG, Neuschwander-Tetri BA. Nonalcoholic steatohepatitis: an expanded clinical entity. Gastroenterology. 1994;107:1103-9.

5. Bacon BR, Powell LW, Adams PC, Kresina TF, Hoofnagle JH. Molecular medicine and hemochromatosis: at the crossroads. Gastroenterology. 1999;116:193-207.

6. Barry E, Derhammer T, Elsea SH. Prevalence of three hereditary hemochromatosis mutan alleles in the Michigan caucasian population. Community Genet. 2005;8:173-9.

7. Bonkovsky HL, Jawaid Q, Tortorelli K, LeClair P, Cobb J, Lambrecht RW, Banne BF. Non-alcoholic steatohepatitis and iron: increased prevalence of mutations of the HFE gene in non-alcoholic steatohepatitis. J Hepatol. 1999;31:421-9.

8. Blendis L, Oren R, Halpern Z. NASH: can we iron out the pathogenesis? Gastroenterology. 2000;118:981-3

9. Brunt EM, Janney CG, Di Bisceglie AM, Neuschwander-Tetri BA, Bacon BR Nonalcoholic steatohepatitis: a proposal for grading and staging the histological lesions. Am J Gastroenterol. 1999;94:2467-74.

10. Bugianesi E, Leone N, Vanni E, Marchesini G, Brunello F, Carucci P, Musso A, DePaolis P, Capunotti L, Salizzoni M, Rizzetto M. Expanding the natural history of nonalcoholic steatohepatitis: from cryptogenic cirrhosis to hepatocellular carcinoma. Gastroenterology. 2002;123:134-40.

11. Bugianesi E, Manzini P, D’Antico S, Vanni E, Longo F, Leone N, Massarenti P, Piga A, Marchesini G, Rizzeto M. Relative contribution of iron burden, HFE mutations, and insulin resistance to fibrosis in nonalcoholic fatty liver. Hepatology. 2004;39:17987.

12. Byrnes V, Ryan E, Barrett S, Kenny P, Mayne P, Crowe J. Genetic hemochromatosis, a Celtic disease: is it now time for population screening? Genet Test. 2001;5:127-30.

13. Caldwell SH, Oelsner DH, Iezzoni JC. Cryptogenic cirrhosis: clinical characterization and risk factors for underlying disease. Hepatology. 1999;29:664-9.

14. Cassanelli S, Pignatti E, Montosi G, Garuti C, Mariano M, Campioli D, Carbonieri A, Baldini E, Pietrangelo A. Frequency and biochemical expression of C282Y/H63D hemochromatosis (HFE) gene mutations in the healthy adult population in Italy. Hepatol. 2001;34:523-8.

15. Chitturi S, Weltman M, Farrell GC, McDonald D, Liddle C, Samarasinghe D, Lin $\mathrm{R}$, Abeygunasekera S, George J. HFE mutations, hepatic iron, and fibrosis: ethnicspecific association of NASH with $\mathrm{C} 282 \mathrm{Y}$ but not with fibrotic severity. Hepatology. 2002;36:142-9.

16. Deguti MM, Sipahi AM, Gayotto LCC, Palácios SA, Bittencourt PL, Goldberg AC Laudanna AA, Carrilho FJ, Cançado ELR. Lack of evidence for the pathogenic role of iron and gene mutations in Brazilian patients with nonalcoholic steatohepatitis. Braz J Med Biol Res. 2003;36:739-45.

17. Desai TK, Chiorean M. Phlebotomy reduces transaminase levels in patients with chronic non-alcoholic steatohepatitis [abstract]. Gastroenterology. 1998;114:A1233.

18. Di Bisceglie AM, Axiotis CA, Hoofnagle JH, Bacon BR. Measurement of iron status in patients with chronic hepatitis. Gastroenterology. 1992;102:2108-13.

19. Diehl AM, Goodman Z, Ishak KG. Alcohol-like liver disease in nonalcoholics. A clinical and histologic comparison with alcohol-induced liver injury. Gastroenterology. 1988;95:1056-62.
20. Feder JN, Gnirke A, Thomas W, Tsuchihashi Z, Ruddy DA, Basava A, Dormishian F, Domingo R, Ellis MC, Fullan A, Hinton LM, Jones NL, Kimmel BE, Kronmal GS, Lauer P, Lee VK, Loeb DB, Mapa FA, McClelland E, Mayer NC, Mintier GA, Moeller N, Moore T, Morikang E, Prass CE, Quintana L, Starnes SM, Schatzman RC, Brunke KJ, Drayna DT, Risch NJ, Bacon BR, Wolff RK. A novel MHC class 1-like gene is mutated in patients with hereditary haemochromatosis. Nat Genet. 1996;13:399-408.

21. Fletcher LM, Halliday JW, Powell LW. Interrelationships of alcohol and iron in liver disease with particular reference to the iron-binding proteins, ferritin and transferrin. J Gastroenterol Hepatol. 1999;14:202-14.

22. Garcia-Monzon C, Martin-Perez E, Iacono OL, Fernandez-Bernejo M, Majano PL, Apolinario A, Larranaga E, Moreno-Otero R. Characterization of pathogenic and prognostic factors of nonalcoholic steatohepatitis associated with obesity. J Hepatol. 2000;33:716-24

23. George DK, Goldwurm S, Macdonald GA, Cowley LL, Walker NI, Ward PJ, Jazwinska EC, Powell LW. Increased hepatic iron concentration in nonalcoholic steatohepatitis is associated with increased fibrosis. Gastroenterology. 1998;114:311-18.

24. Grove J, Daly AK, Burt AD, Guzail M, James OF, Bassendine MF, Day CP. Heterozygotes for HFE mutations have no increased risk of advanced alcoholic liver disease. Gut. 1998;43:262-6.

25. Jazwinska EC, Cullen LM, Busfield F, Pyper WR, Webb SI, Powell LW, Morris CP, Walsch TP. Hemochromatosis and HLA-H. Nat Genet. 1996;14:249-51.

26. Ludwig J, Viggiano TR, Mcgill DB, Ott B. Nonalcoholic steatohepatitis. Mayo Clinic experiences with a hitherto unnamed disease. Mayo Clin Proc. 1980;55:434-8.

27. National Institutes of Health. Symposium on Non-alcoholic Steatohepatitis. Bethesda, Maryland; 1998. (Syllabus).

28. Olynyk JK, Cullen DJ, Aquilia S, Rossi E, Summerville L, Powell LW. A populationbased study of the clinical expression of the hemochromatosis gene. N Engl J Med. 1999;341:718-24.

29. Powell EE, Cooksley WG, Hanson R, Searle J, Halliday JW, Powell L. The natural history of nonalcoholic steatohepatitis: a follow-up study of forty-two patients for up to 21 years. Hepatology. 1990;11:74-80.

30. Ratziu V, Giral P, Charlotte F, Bruckert E, Thibault V, Theodorou I, Khalil L, Turpin G, Opolon P, Poynard T. Liver fibrosis in overweight patients. Gastroenterology. 2000;118:1117-23.

31. Risch N. Haemochromatosis, HFE and genetic complexity. Nat Genet. 1997;17:375-86.

32. Schaffner F, Adler M. Fatty liver hepatitis and cirrhosis in obese patients. Am J Med. 1979;67:811-6.

33. Sorbi D, Boynton J, Lindor KD. The ratio of aspartate aminotransferase to alanine aminotransferase: potential value in differentiating nonalcoholic steatohepatitis from alcoholic liver disease. Am J Gastroenterol. 1999:94:1018-22.

34. Wanless IR, Lentz JS. Fatty liver hepatitis (steatohepatitis) and obesity: an autopsy study with analysis of risk factors. Hepatology. 1990;12:1106-10.

35. Younossi Z, Diehl AM, Ong JP. Nonalcoholic fatty liver disease: an agenda for clinical research. Hepatology. 2002;35:746-52.

36. Younossi ZM, Gramlich T, Bacon BR, Matteoni CA, Boparai N, O'Neill R, McCullough AJ. Hepatic iron and nonalcoholic fatty liver disease. Hepatology. 1999;30:847-50.

37. Zamin IJ, Mattos AA, Zettler CG. Non-alcoholic steatohepatitis in nondiabetic obese patients. Can J Gastroenterol. 2002;16:303-8. 